\title{
The use of early lactation milk protein content to predict subsequent fertility performance and likelihood of culling, in commercial dairy cows
}

\author{
M.J. Tena-Martínez ${ }^{1}$, D. Val-Arreola ${ }^{1,3}$, J.D. Hanks ${ }^{2}$ \\ and N.M. Taylor ${ }^{2}$ \\ ${ }^{1}$ Michoacan University of Saint Nicolas of Hidalgo \\ Morelia-Zinapecuaro Road, km. 9.5 Tarímbaro, Michoacan 58880, Mexico \\ ${ }^{2}$ Veterinary Epidemiology and Economics Research Unit (VEERU), School of Agriculture, \\ Policy and Development, University of Reading \\ P.O. Box 237, Reading RG6 6AR, United Kingdom
}

(Received 1 September 2008; revised version 7 January 2009; accepted 20 March 2009)

\begin{abstract}
A dataset of 1,846,990 completed lactation records was created using milk recording data from 8,967 commercial dairy farms in the United Kingdom over a five year period. Herd-specific lactation curves describing levels of milk, fat and protein by lactation number and month of calving were generated for each farm. The actual yield of milk and protein proportion at the first milk recording of individual cow lactations were compared with the levels taken from the lactation curves. Logistic regression analysis showed that cows producing milk with a lower percentage of protein than average had a significantly lower probability of being in-calf at 100 days post calving and a significantly higher probability of being culled at the end of lactation. The culling rates derived from the studied database demonstrate the current high wastage rate of commercial dairy cows. Much of this wastage is due to involuntary culling as a result of reproductive failure.
\end{abstract}

KEY WORDS: fertility, probability of culling, milk protein, milk records

\section{INTRODUCTION}

As farmers strive to reduce costs and maximize their income, average herd size and lactation yield in United Kingdom herds have increased steadily (Dairy

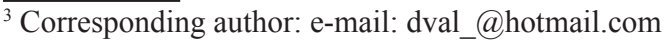


Council, 2003). Milk yields are frequently the overriding focus of management and genetic selection (Lucy, 2000). In common with intensive systems elsewhere, the general rise in milk production in the United Kingdom is associated with a decline in the levels of fertility (Royal et al., 2000; Westwood et al., 2002), therefore annual culling rates now exceed $30 \%$ of cows in many dairy herds, with failure to conceive being a major reason (Dairy Council, 2003; Dairy Research International, 2003; Gröhn et al., 2003; Rajala-Shultz and Fraser, 2003). Higher milk yields increase the likelihood of extended periods of negative energy balance in the early lactation (Beam and Butler, 1999; Royal et al., 2000); the consequences of extended negative energy balance are longer post-partum anoestrus intervals (Beam and Butler, 1997), reduced embryo survival (Dunne et al., 1999) and reduced display of oestrus (Washburn et al., 2002); a common economic consequence of excessive delay in conception often result in a decision to cull the cow (Arbel et al., 2001; Esslemont and Kossaibati, 2002). Protein content of milk is linked to the energy status of the dairy cow, thus, during times of energy deficit milk protein proportion has been shown to decrease (Grieve et al., 1986; Heuer et al., 1999; Reksen et al., 2002). The aim of this study was to test the association between the deviation statistics of the cows' milk components and the subsequent fate of cows, in order to build a potential indicator for cows performing outside adjusted herd average norms. The value of this statistic as a management indicator was also assessed.

\section{MATERIAL AND METHODS}

\section{Herd-specific lactation curves}

The concept of the lactation curve developed by Wood (1969) is applied in the InterHerd ${ }^{\mathrm{TM}}$ software to generate herd-specific lactation curves through the analysis of historical milk recording data for each herd (PAN Livestock Services, 2003). The central equation used by Woods to describe the lactation curve is:

$$
Y_{n}=a n^{b} \exp ^{(-c n)} m_{1} \cdot m_{2} \cdot m_{3} \ldots m_{12}
$$

where: $Y_{n}$ - the average daily milk in $n$th week, an is the initial milk yield just after calving; $b$ - the inclining slope parameter up to peak yield; $c n$ - the declining slope parameter; $m_{i}$ - month of production adjustments.

Similar formulae were used to describe the production of milk protein and fat.

Herd-specific regression using historical milk recording data for cows in three lactation groups (Parities 1, 2 and 3+) were performed to fit the constants in Woods' equation. The resulting formulae were then used to generate herd-specific curves that show production of milk, protein and fat for the average cow in that herd, adjusted for lactation number, days since calving and month of production. 


\section{The dataset}

Complete lactation records were obtained from National Milk Records (NMR) from commercial farms between September 1997 and October 2003. The dataset contained information for individual lactation including the fate, herd, actual and herd-average lactation information. If a cow re-calved at the end of the parity, its pregnancy status at 100 and 200 days post-calving was derived from the re-calving date. The actual somatic cell count (SCC) was also included, being a known factor influencing culling decisions. The dataset was created according to the following criteria for inclusion in the analysis: A cow's parity record required a milk recording between day 15 and day 80 of the parity with full milk composition results. The cow must also have completed the parity with one of two possible fates (outcomes): i. re-calved (the cow calved again to start a new parity) and ii. culled (the cow left the herd without calving again). Parities that ended in the death of the cow ( $2 \%$ of all parities) were excluded from the analysis.

For the first milk recording in each parity between day 15 and day 80 (1stMR), deviation statistics were calculated for milk yield and proportions of milk fat and protein. These were derived by subtracting the herd average value, with adjustment for the animal's parity, month of calving and days since calving (the 'adjusted herd average'), from the actual recorded value.

\section{Descriptive statistics}

The initial dataset comprised of 1,846,990 parity records from 921,242 different cows on 8,967 farms. Table 1 details the distribution of records in the dataset by parity, fate and pregnancy status at 100 and 200 days post-calving. The culling percentage ranges from $16 \%$ of cows in parity 1 to $38 \%$ of cows in parity 4 or higher $(4+)$. The overall cull rate was $26 \%$.

Up to and including parity 3, around $40 \%$ of cows had conceived within 100 days of calving, rising to around $70 \%$ within 200 days. For cows in parity 4+ these figures were much lower, 28 and $50 \%$, respectively. Based on the re-calving percentages showed in Table 2, an estimated cohort of 100 cows in parity 1 that would survive to subsequent parities, it can be assumed that more than $50 \%$ of cows would fail to survive beyond parity 3 .

Table 1. Distribution of cow records by parity in the dataset

\begin{tabular}{lrrrrrrrc}
\hline Parity & $\begin{array}{c}\text { Cow } \\
\text { records }\end{array}$ & $\begin{array}{c}\text { No. } \\
\text { re-calved }\end{array}$ & $\begin{array}{c}\text { No. } \\
\text { died }\end{array}$ & $\begin{array}{c}\text { No. } \\
\text { culled }\end{array}$ & $\begin{array}{c}\text { In-calf at } \\
100 \text { days } \\
\%\end{array}$ & $\begin{array}{c}\text { In-calf at } \\
200 \text { days } \\
\%\end{array}$ & $\begin{array}{c}\text { Culled } \\
\%\end{array}$ & $\begin{array}{c}\text { Re- } \\
\text { calved } \\
\%\end{array}$ \\
\hline Parity 1 & 486677 & 401674 & 8095 & 76908 & 41 & 73 & 16 & 83 \\
Parity 2 & 408150 & 320467 & 6944 & 80739 & 40 & 71 & 20 & 79 \\
Parity 3 & 317484 & 235894 & 6442 & 75148 & 39 & 67 & 24 & 74 \\
Parity 4+ & 634679 & 377632 & 18993 & 238054 & 28 & 50 & 38 & 59 \\
Overall & 1846990 & 1335667 & 40474 & 470849 & 37 & 65 & 26 & 72 \\
\hline
\end{tabular}




\section{Logistic regression analysis}

Binary logistic regression models were developed using SAS (1999) with fate, either culled or re-calved, as the dependent variable. A range of potential explanatory variables, as shown in Table 2, were tested. Different combinations of the variables were tested for their ability to predict the likelihood that a cow is subsequently culled. Models were built manually in a stepwise manner. Experimentation with different order of variable addition and subtraction was carried out. The significance of different factors in the model was assessed using the change in deviance due to the addition factor to the model. This is based on an approximated $\chi^{2}$ test (Collett, 1999). Having found the combination of the variables that best predicted culling outcome the association of these variables with fertility (the probability of being in-calf at 100 days post-calving) was then assessed. All the analyses were conducted separately for four parity sub-groups: parity 1 , parity 2 , parity 3 and parity 4 or higher.

Table 2. Explanatory variable tested in the analysis

\begin{tabular}{|c|c|}
\hline Actual yield & the recorded yield of milk $(\mathrm{kg})$ at the 1 stMR \\
\hline Actual protein proportion & the recorded proportion of milk protein at the 1 stMR \\
\hline Actual fat proportion & the recorded proportion of milk fat at 1 stMR \\
\hline Actual SCC & the recorded somatic cell count at the 1 stMR \\
\hline Yield deviation & $\begin{array}{l}\text { the recorded milk yield less the adjusted herd average milk yield at } \\
\text { the } 1 \text { stMR }\end{array}$ \\
\hline Protein deviation & $\begin{array}{l}\text { the recorded protein proportion less the adjusted herd average protein } \\
\text { proportion at the } 1^{\text {st }} \mathrm{MR}\end{array}$ \\
\hline Fat deviation & $\begin{array}{l}\text { the recorded fat proportion less the adjusted herd average fat proportion } \\
\text { at the } 1 \mathrm{stMR}\end{array}$ \\
\hline Fat/protein ratio & $\begin{array}{l}\text { the recorded fat proportion divided by the recorded protein proportion } \\
\text { at the } 1 \text { stMR }\end{array}$ \\
\hline LogAvSCC305 & $\begin{array}{l}\text { logarithmic transformation of the average somatic cell count recorded } \\
\text { at all milk recordings in the same parity as the } 1 \text { stMR }\end{array}$ \\
\hline LogActual SCC & $\begin{array}{l}\text { logarithmic transformation of the somatic cell count recorded at the } \\
1 \text { stMR }\end{array}$ \\
\hline Herd identifier & a variable identifying the specific herd in which the cow was located \\
\hline
\end{tabular}

\section{RESULTS}

A number of variables were excluded from the model due to the limited impact that their inclusion had on the dependent variable. These excluded variables were herd identifier, fat/protein ratio and fat deviation.

An initial analysis of the relationship between protein proportion and culling probability, without consideration of a cow's yield, suggested that cows with higher protein proportions were more likely to be culled. This contradicted the expectation that cows producing milk with lower protein proportions would have 
higher culling probability because of the link with negative energy balance and poor fertility. However, the data showed a negative correlation between the protein proportion and yield of milk at 1stMR. This was as expected, because cows with high milk yields generally produce milk with lower proportions of protein. Since farmers resist culling cows with higher yields there is a potential for confounding of the effects of milk yield and protein proportion on culling probability. Therefore it was necessary to include both milk yield and protein proportion in all models. The resulting models predicted increasing culling probability with both decreasing yield and decreasing protein proportion.

The use of deviation statistics related to milk yield and protein proportion, rather than the measures per se, resulted in a better fitting model. Adding either of the SCC variables significantly improved the model showing these are significant factors affecting the probability of a cow being culled. Inclusion of the logarithmic transformation of the SCC at the 1stMR resulted in a better fitting model than using the logarithmic transformation of the average SCC from milk recordings to day 305 of the lactation.

All the variables included in the final models were highly significant, showing that a combination of the deviation statistic for milk protein proportion and milk yield combined with the log of the actual SCC provided the best prediction of fate of the cow. The parameters of the models for likelihood of culling for parity groups $1,2,3$ and $4+$ are displayed in Table 3 . The same three explanatory variables were also used in a logistic regression model describing the likelihood of a cow being in-calf at 100 days post calving. The parameters of these models are displayed in Table 4.

Table 3. Binary Logistic Regression Models describing the probability of culling

\begin{tabular}{lcccccccc}
\hline \multirow{2}{*}{ Parameter } & \multicolumn{3}{c}{ Parity 1 } & \multicolumn{2}{c}{ Parity 2 } & \multicolumn{2}{c}{ Parity 3 } & \multicolumn{2}{c}{ Parity 4+ } \\
\cline { 2 - 9 } & estimate & P-value & estimate & P-value & estimate & P-value & estimate & P-value \\
\hline Intercept & -2.39 & $<0.001$ & -2.16 & $<0.001$ & -2.05 & $<0.001$ & -1.56 & $<0.0001$ \\
Yield deviation & -0.07 & $<0.001$ & -0.05 & $<0.001$ & -0.05 & $<0.001$ & -0.06 & $<0.0001$ \\
Protein deviation & -4.60 & 0.007 & -23.33 & $<0.001$ & -32.35 & $<0.001$ & -63.79 & $<0.0001$ \\
LogActual SCC & 0.19 & $<0.001$ & 0.21 & $<0.001$ & 0.23 & $<0.001$ & 0.25 & $<0.0001$ \\
Log likelihood & -197825.2 & -189113.4 & -160179.7 & -375866.1 \\
\hline
\end{tabular}

Table 4. Binary Logistic Regression Models describing the probability of being in-calf at 100 days post calving

\begin{tabular}{lcccccccc}
\hline \multirow{2}{*}{ Parameter } & \multicolumn{2}{c}{ Parity 1 } & \multicolumn{2}{c}{ Parity 2 } & \multicolumn{2}{c}{ Parity 3 } & \multicolumn{2}{c}{ Parity 4+ } \\
\cline { 2 - 9 } & estimate & P-value & estimate & P-value & estimate & P-value & estimate & P-value \\
\hline Intercept & 0.12 & $<0.0001$ & 0.05 & $<0.0001$ & 0.11 & $<0.0001$ & -0.01 & 0.2168 \\
Yield deviation & 0.01 & $<0.0001$ & 0.006 & $<0.0001$ & 0.01 & $<0.0001$ & 0.26 & $<0.0001$ \\
Protein deviation & 38.00 & $<0.0001$ & 35.36 & $<0.0001$ & 38.62 & $<0.0001$ & 57.47 & $<0.0001$ \\
LogActual SCC & -0.12 & $<0.0001$ & -0.11 & $<0.0001$ & -0.14 & $<0.0001$ & -0.17 & $<0.001$ \\
Log likelihood & -310704.1 & -259948.0 & -199133.3 & -365271.8 \\
\hline
\end{tabular}


Figure 1 shows graphically the relationship between the protein deviation statistic and culling probability, based on the regression model equation, for five scenarios illustrating different combinations of yield deviation and SCC level (Table 5).

Figure 2 shows graphically the relationship between the protein deviation statistic and probability of being in-calf at 100 days post calving, based on the

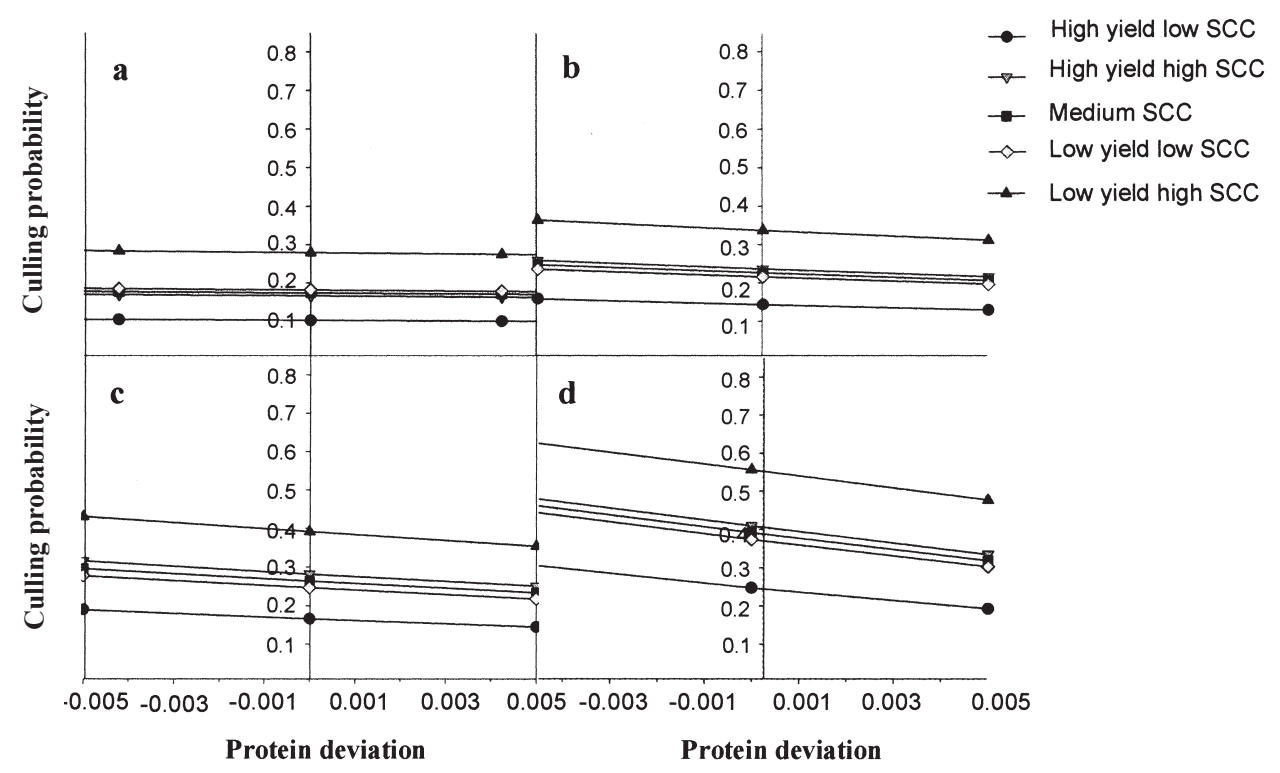

Figure 1. Culling probability in parity 1 (a), 2 (b), 3 (c) and $4+($ d) cows as a function of protein deviation at 1 stMR

Table 5. Five scenarios of yield deviation and SCC level used in Figures 3 to 10

\begin{tabular}{ll}
\hline Scenario & \multicolumn{1}{c}{ Description } \\
\hline High yield, low SCC & $\begin{array}{l}\text { A cow yielding } 5 \mathrm{~kg} \text { milk more than adjusted herd average and a } \\
\text { somatic cell count reading of } 100000 \text { at the } 1 \mathrm{stMR}\end{array}$ \\
High yield, high SCC & $\begin{array}{l}\text { A cow yielding } 5 \mathrm{~kg} \text { milk more than adjusted herd average and a } \\
\text { somatic cell count reading of } 850000 \text { at the } 1 \mathrm{stMR}\end{array}$ \\
Average yield, medium SCC & $\begin{array}{l}\text { A cow yielding the adjusted herd average and a somatic cell } \\
\text { count reading of } 300000 \text { at the } 1 \text { stMR }\end{array}$ \\
Low yield, low SCC & $\begin{array}{l}\text { A cow yielding } 5 \mathrm{~kg} \text { milk less than adjusted herd average and a } \\
\text { somatic cell count reading of } 100000 \text { at the } 1 \text { stMR }\end{array}$ \\
Low yield, high SCC & $\begin{array}{l}\text { A cow yielding } 5 \mathrm{~kg} \text { milk less than adjusted herd average and a } \\
\text { somatic cell count reading of } 850000 \text { at the } 1 \mathrm{stMR}\end{array}$ \\
\hline
\end{tabular}




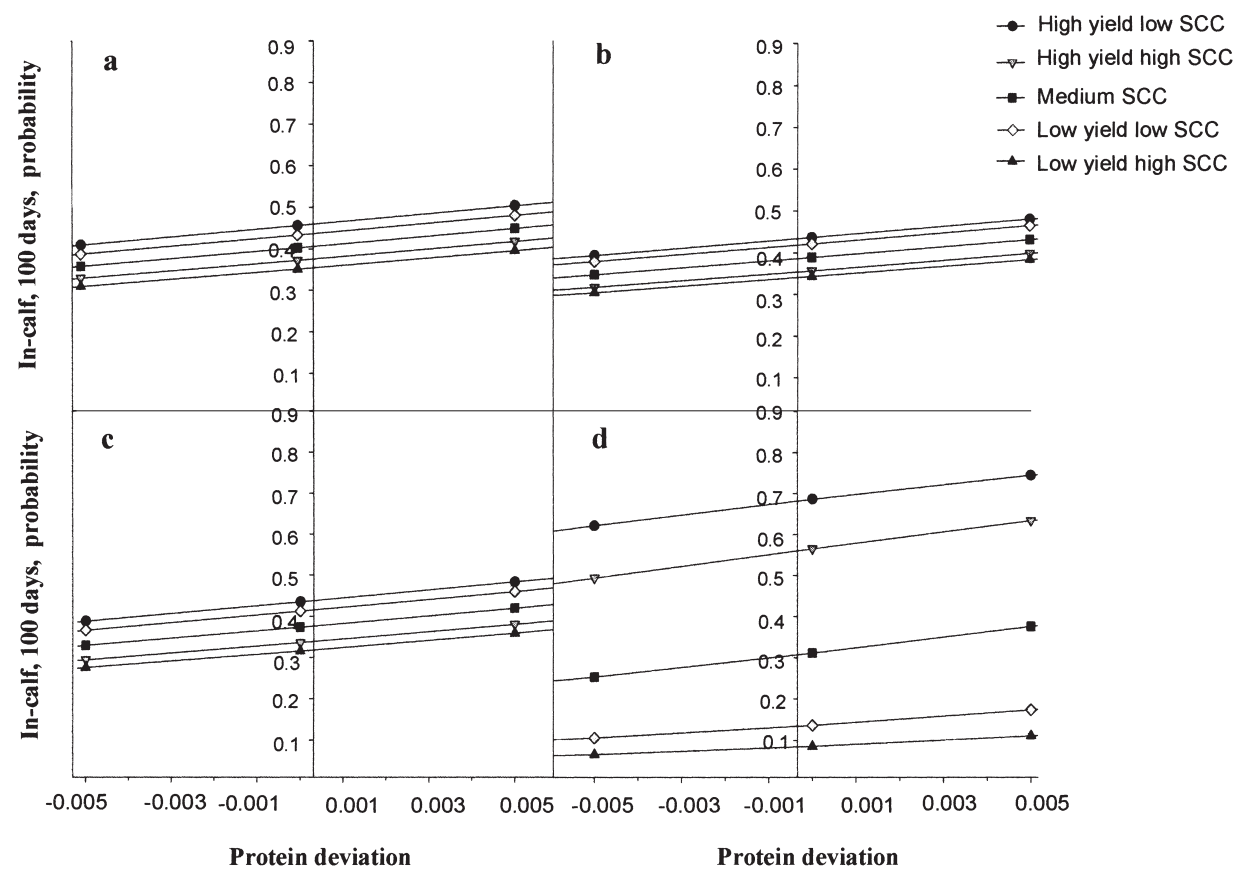

Figure 2. In-calf probability at 100 days post-calving in parity 1 (a), 2 (b), 3 (c) and 4+ (d) cows as a function of protein deviation at 1 stMR

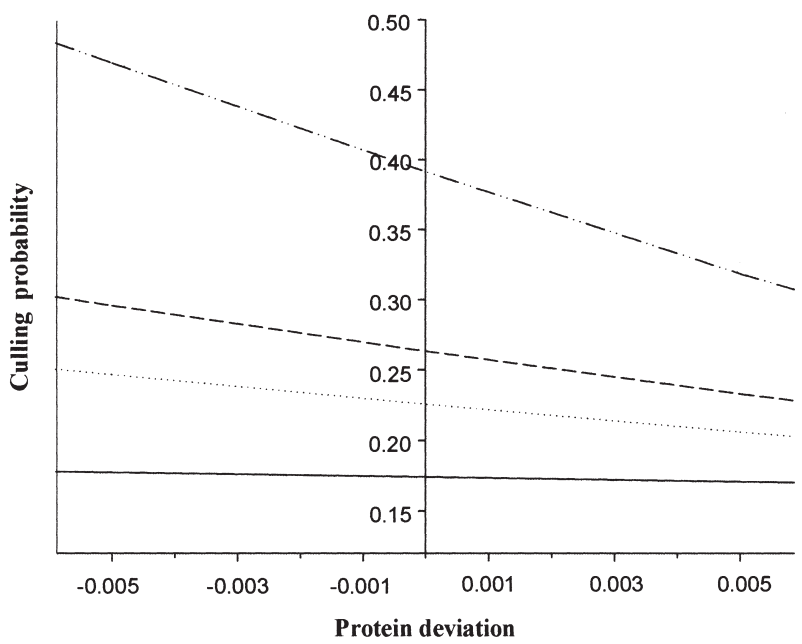

Figure 3. Culling probability by parity as a function of protein deviation at 1 stMR for cows yielding milk as adjusted herd average and medium SCC level (parity 1 -, parity $2 \cdots \cdots$, parity $3--$, parity $4+-\cdot \cdot-$ ) 
regression model equation, for the same five scenarios. The low, medium and high somatic cell count values used in the scenarios in Table 5 are based on ranges described by the National Mastitis Council (2000).

Cows with protein proportions below the adjusted herd average (a negative deviation) have an increased probability of culling. The culling probability in all parity groups was also higher in the cows with higher SCC and below adjusted herd average yields recorded at the 1stMR. Figure 1 shows that the effect of protein deviation differs with parity number. Figure 3 compares the parity groups for a single scenario (average yield, medium SCC). The steeping curves in Figure 3 show that the effect of the protein deviation on the probability of culling strengthens as parity number increases. The effect of protein deviation on culling probability in parity 1 is slight, though still statistically significant, whereas the effect is markedly stronger in parity $4+$ cows than in other parity groups.

Cows with protein proportions below the adjusted herd average (a negative deviation) have a decreased probability of being in-calf at 100 days. For cows in parity $4+$, the in-calf at 100 days post-calving probability was much lower for cows with below adjusted herd average yields recorded at the 1stMR. In other parity groups (1-3) the in-calf at 100 days post-calving probability was slightly lower than average for cows with higher SCC.

Figure 4 compares the in-calf at 100 days post-calving probability between parity groups for a single scenario (average yield, medium SCC). The curves for parity 1 to 3 cows in Figure 4 have similar gradients, showing that the effect of the

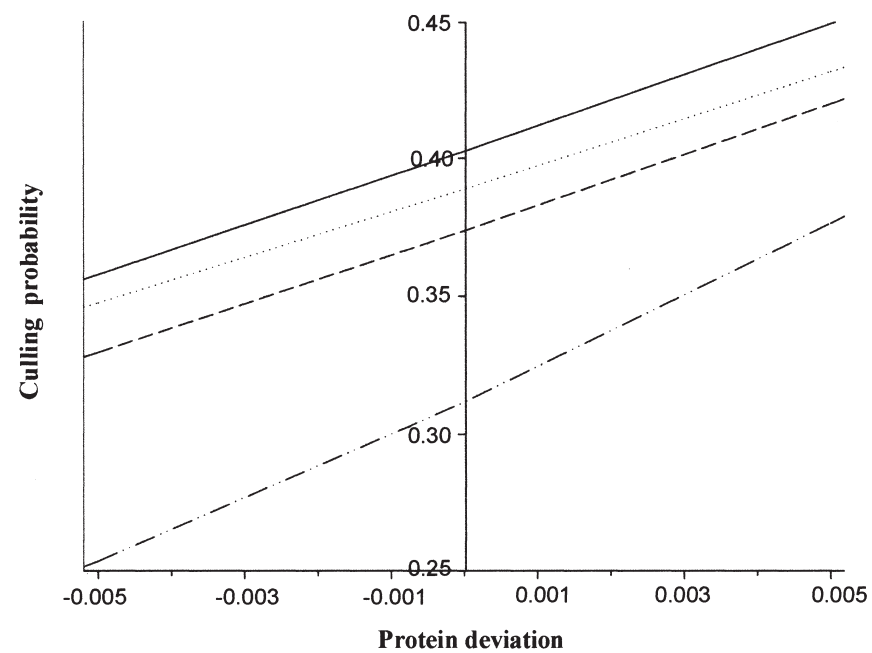

Figure 4. In-calf probability by parity as a function of protein deviation at 1 stMR for cows yielding milk as adjusted herd average and medium SCC level (parity $1-$, parity $2 \cdots$, parity $3--$, parity $4+$ $-. \cdot-)$ 
protein deviation on in-calf probability is similar in these parities. The curve for parity $4+$ cows is slightly steeper, suggesting a stronger effect.

\section{DISCUSSION}

This analysis, based on a very large dataset of recent lactation records derived from over $40 \%$ of commercial herds in Great Britain, highlights the very high culling rates that persist in modern dairy systems. That the majority of cows fail to reach their fourth lactation represents a massive waste of resources. A high culling rate entails the need to rear more replacements and many of them will have a reduced life as productive milking cows.

The analyses of herd-specific lactation curves, based on historical milk records of all cows on a farm, provided a basis for within-herd comparison of yields of milk and its constituents. This enables comparison of each cow's actual production on any milk recording date against a herd standard that is adjusted for the parity, month of calving and days into lactation.

Use of deviation statistics accounted for variation between herds, parity and month of calving. It is of note that a herd identifier did not add a significant level of explanation to any model containing deviation statistics. The use of such deviation statistics in studies that compare performance of cows in a number of different herds, such as that employed for sire proofing (Wall et al., 2003), may provide a clearer indication of the true differences between progeny.

The findings of this study support the link between milk protein proportion and energy metabolism in the dairy cow (Grieve et al., 1986; Heuer et al., 1999; Reksen et al., 2002). A negative deviation in protein proportion in early lactation is believed to reflect a shortage of energy that will have a negative impact on fertility (Beam and Butler, 1997; Dunne et al., 1999; Washburn et al., 2002). This analysis demonstrates a link between the protein deviation statistic and the probability of a cow being in-calf at 100 days after calving. Poor fertility performance is known to be a major cause of culling, hence the association between the protein deviation statistic and the culling probability shown in this research.

Actual milk fat proportion, fat deviation and fat:protein ratio variables were not significantly associated with culling probability suggesting that the milk protein proportion is a superior indicator of negative energy balance than milk fat parameters.

It was observed that the consequences of protein deviation, in terms of culling probability, differ markedly between parities. In parity 1 , the effect of protein deviation on culling probability, though statistically significant, is practically negligible (Figure 2a). For older cows, particularly those in parities 4 and above, a negative protein deviation materially increase the probability of being culled 
(Figure 2d). The protein deviation has a similar effect on the probability of being in-calf at 100 days after calving in all parities. It therefore follows that failure to conceive early in lactation results in a culling decision more readily for older cows than younger ones, especially first parity animals. It is possible that farmers are more willing to re-serve younger cows more often than older ones. In addition, farmers cull first parity cows for a wide range of reasons, for example behavioural or conformation problems, which may dilute any effect of fertility problems on culling probability. The markedly higher impact of protein deviation on culling probability in the parity $4+$ group suggests that fertility plays a more prominent role in culling decisions in older cows. It is possible that the protein deviation is also linked to other factors leading to culling decisions, such as chronic mastitis and lameness. Within the current database there is potential to explore further the relationship between protein deviation and SCC profiles.

\section{CONCLUSIONS}

The results of these analyses show that milk protein, milk yield and somatic cell counts obtained from routine milk recording in early lactation (from day 15 to day 80 after calving) are strongly associated with the fertility performance and subsequent fate of the dairy cow.

If the very high culling rates currently observed are to be reduced, more attention should be focused on managing the early lactation cow. In herds with high culling rates, farmers should target minimizing negative energy balance in early lactation, so that fertility is optimized, rather than maximizing milk output. On most farms newly calved cows are all managed together and fed for maximum yield irrespective of the age of the animals concerned. This research suggests that culling rates, particularly in older cows, would be significantly reduced by managing these animals separately in a less demanding system.

The protein deviation statistic provides a practical tool for the monitoring of energy balance in the commercial dairy herd. Milk recording organizations and farm advisers can readily identify animals or groups of animals that are producing milk with lower protein proportions. Further investigation is needed to identify critical levels of protein deviation to trigger management interventions. The fact that the milk recording data are routinely, and rapidly available should make this a more effective early warning of energy deficit than alternatives such as body condition scoring and metabolic profiles which require additional time and effort from the farmer. 


\section{ACKNOWLEDGEMENTS}

The authors are grateful to National Milk Records (NMR) for their co-operation in providing access to the data and in the derivation of the database. The funding of The National Council for Science and Technology is also readily acknowledged. The authors are also grateful for the major contributions of Dr Andrew James, of the Veterinary Epidemiology and Economics Research Unit (VEERU) and Dr Derek Pike, Head of the School of Applied Statistics both at the University of Reading.

\section{REFERENCES}

Arbel R., Bigun Y., Ezra E., Sturma H., Hojman D., 2001. The effect of extended calving intervals in high lactating cows on milk production and profitability. J. Dairy Sci. 84, 600-608

Beam S.W., Butler W.R., 1997. Energy balance and ovarian follicle development prior to the first ovulation in postpartum in dairy cows receiving three levels of dietary fat. Biol. Reprod. 56, 133-142

Beam S.W., Butler W.R., 1999. Effects of energy balance on follicular development and first ovulation in postpartum dairy cows. J. Reprod. Fertil. 54, Suppl., 411-424

Collett D., 1999. Modelling Binary Data. Chapman \& Hall/CRC. London

Dairy Council, 2003. Dairy Facts and Figures 2002 Edition. The Dairy Council. London, pp. 11-35, $81-87$

Dairy Research International, 2003. Dairy Economic Indicators. Dairy Research International. Surrey, pp. 39-51

Dunne L.D., Diskin M.G., Boland M.P., O’Farrel K.J., Sreeman J.M., 1999. The effect of pre- and post-insemination plane of nutrition on embryo survival in beef heifers. Anim. Sci. 69, 411417

Esslemont R.J., Kossaibati M.A., 2002. The cost of disease and poor fertility in dairy herds. In: Daisy Report No. 5. 12A Salcombe Drive, Earley, Reading RG6 7HU (UK), pp. 5-21, 117-125

Grieve D.G., Korver S., Rijpkema Y.S., Hof G., 1986. Relationship between milk composition and some nutritional parameters in early lactation. Livest. Prod. Sci. 14, 239-254

Gröhn Y.T., Rajala-Schultz P.J., Allore H.G., DeLorenzo M.A., Hertl J.A., Galligan D.T., 2003. Optimizing replacement of dairy cows: modeling the effects of diseases. Prev. Vet. Med. 61, $27-43$

Heuer C., Schukken Y. H., Dobbelaar P., 1999. Postpartum body condition score and results from the firs test day milk as predictors of disease, fertility, yield, and culling in commercial dairy herds. J. Dairy Sci. 82, 295-304

Lucy M.C., 2000. Regulation of ovarian follicular growth by somatotropin and insulin-like growth factors in cattle. J. Dairy Sci. 83, 1635-1647

National Mastitis Council (USA), 2000. Procedures for improving udder health. Report on-line at http://nmconline.org/uddrhlt.htm. Last consulted October 2004

PAN Livestock Services, 2003. The InterHerd herd management package. In: User Guide. PAN Livestock Services. Reading (UK)

Rajala-Schultz P.J., Frazer G.S., 2003. Reproductive performance in Ohio dairy herds in the 1990's. Anim. Reprod. Sci. 76, 127-142 
Reksen O., Havrevoll Ø., Gröhn Y.T., Bolstad T., Waldmann A., Ropstad E., 2002. Relationships among body condition score, milk constituents, and postpartum luteal function in Norwegian dairy cows. J. Dairy Sci. 85, 1406-1415

Royal M.D., Darwash A.O., Flint A.P.F., Webb R., Woolliams J.A., Lamming, V., 2000. Declining fertility in dairy cattle: changes in traditional and endocrine parameters of fertility. Anim. Sci. 70, 487-502

SAS, 1999. SAS/STAT ${ }^{\circledR}$ User's Guide, Version 8, In: Chapter 29 - The GEMOD Procedure and The REG Procedure in Chapter 55. Cary, NC

Wall E., Brotherstone S., Woolliams J.A., Banos G., Coffey M.P., 2003. Genetic evaluation of fertility using direct and correlated traits. J. Dairy Sci. 86, 4093-4102

Washburn S.P., Silvia W.J., Brown C. H., McDaniel B.T., McAlister A.J., 2002. Trends in reproductive performance in South-eastern Holstein and Jersey DHI herds. J. Dairy Sci. 85, 244-251

Westwood C.T., Lean I.J., Garvin J.K., 2002. Factors influencing fertility of Holstein dairy cows: a multivariate description. J. Dairy Sci. 85, 3225-3237

Wood P.D.P., 1969. Factors affecting the shape of the lactation curve in cattle. J. Anim. Prod. 11, 307-316 